\title{
New challenges in the financial management under the influence of financial technology
}

\author{
Raigul Doszhan ${ }^{1, *}$, Azhar Nurmaganbetova ${ }^{1}$, Ryszard Pukala ${ }^{2}$, Gulmira Yessenova ${ }^{3}$, Serik \\ Omar $^{1}$, Ademi Sabidullina ${ }^{1}$ \\ ${ }^{1}$ Al-Farabi Kazakh National University, al-Farabi Ave. 71, 050040 Almaty, Kazakhstan \\ ${ }^{2}$ The Bronisław Markiewicz State Higher School of Technology and Economics in Jarosław, \\ Czarnieckiego 16, 37-500 Jarosław, Poland
}

${ }^{3}$ L.N. Gumilyov Eurasian National University, Satpayev Str. 2, 010008 Nursultan, Kazakhstan

\begin{abstract}
Fintech, as they call companies that use the latest developments in the field of mobile payments, online lending, digital instant money transfers and other breakthrough technologies in building their business models. Organizations built on such models today are at the forefront of the latest technologies. The purpose of this article is to reveal the essence of the new concept and identify new challenges facing new financial technologies in Kazakhstan and foreign countries. The article discusses the concepts of financial management and financial technologies and their impact on the development of the economy, analyzes the indicators of the development of financial technologies in Kazakhstan and foreign countries, and identifies problems. During the writing of this thesis the theoretical methods, a comparison and a statistical methods were used. The periodicals of modern literature, magazines and Internet resources were used in this work. The theoretical and practical significance of the work consists in a broader disclosure of the conceptual apparatus and the possibility of using the results obtained in the course of the research in the activities of various institutions to develop measures to improve their activities. Keywords: financial management; effectiveness; financial technologies; economic challenges, digital technology, mobile wallets, cryptocurrency.
\end{abstract}

\section{Introduction}

The financial technologies (FinTech) transform the landscape of financial services. FinTech is not a new phenomenon, it is undergoing constant innovation and evolution over the centuries. At the same time, rapid technological progress and consumer preferences for digital solutions are driving the adoption of new business models and the entry of more flexible non-financial companies (in the areas of telecommunications and technology) to the market, offering customers "banking-related services" in the main areas of banking operations, including retail and bulk payments, customer relations, lending and equity raising, as well as financial market infrastructure, asset management and insurance [1]. In economic and scientific literature researches do not provide a unified, generally accepted

\footnotetext{
* Corresponding author: rdd2011@mail.ru
} 
opinion on the nature and role of Financial Management (FM) and 'Fintech', which results in the existence of diverse definitions.

FM is a part of management processes integrated in company management [2]. FM is associated with the attraction of financial resources and their efficient utilization for the achievement of the company's objective. FM is an operation activity in business responsible for the acquisition of funds necessary for an effective performance and their efficient use. B. Howard and M. Upton regard the FM as "an application of general managerial principles to the area of financial decision-making" [3, 4]. All the above definitions and other opinions have a common acknowledgement that financial resources represent the source of economic benefit of a company; however, neither of these definitions mentions business goals and strategies [5]. Research of scientific and economic literature also revealed other views of the essence and role of the FM in market and investment economy. The emerging role of the FM is associated with the formation of a special industry of financial services and the necessity of management of company's value, as it is indicated by Stanchu [6, 7].

\section{Literature review}

With the general growth of economic work on the development of modern technology of the world in many academic fields, it is hardly surprising that the relationship between technology and the management of the world has attracted considerable attention in recent years. Some aspects of technological and digital development are considered in the research of the authors as Ziyadin, S., Doszhan, R., Borodin, A., Omarova, A., Ilyas, A., Saparova, G., Ermekbaeva, B., Supugaliyeva, G., Zharaskyzy, G., Mukhtarova, K., Kupeshova, S. [8, $9,10,11,12]$.

While some research has focused only on the description of differences, other work has sought to how the development of management of the state factional environment and their advisability. Technological innovation is the fundamental driving force of industrial evolution. Schumpeter [13] built the theory of innovation based on the combination of technology and economics. He proposed the concept of innovation to argue that technological change leads to unbalanced economic growth and unstable social development. He believed that innovation is the driving force behind economic development and promotes industrial change and economic structural changes.

After carefully analyzing of various academic sources there have compiled a list of the most valuable to particular study. Fintech in the Asian Development Bank: we have found this work to be particularly interesting and relevant to our studies. This study can be used in perfect conjunction to other studies to agree or even oppose modern views regarding the running of the Fintech and economies. This publication looks at all aspects of the research and pays special attention to key issues [1].

Important and valuable works applied during the writing of the article were also World Bank [14], International Monetary Fund (2017) and the state program "Digital Kazakhstan", where the impact of financial technologies on the economy was fully reflected in a digital format, thanks to which we can speak of a sufficiently large impact and changes.

\section{Methodology}

The information base of the work consists of documents of the official authorities of the Republic of Kazakhstan, as well as foreign and domestic scientific literature, and publications in scientific collections. The work also used information and reporting materials of the National Bank of the Republic of Kazakhstan, as well as materials of Internet resources. 
Many scientists have considered the theoretical aspects of financial management for many years, and this issue remains relevant until now, since not only management itself develops and improves, but also together with it develops financial technologies and the global economy as a whole. From various methodological positions, the problems of influence of financial technologists have investigated a number of well-known scientists, both foreign and domestic. The theoretical significance of the thesis is a broader disclosure of the conceptual apparatus and the development of the theory of financial regulation and its importance in ensuring the development of the economy.

During the writing of this thesis were used the theoretical methods, a comparison and a mathematical-statistical methods. At the time of writing were used periodicals of modern literature, magazines and internet resources.

The term 'Fintech' denotes 'financial technology' and is defined as the delivery of financial and banking services through modern technological innovation led by computer programs and algorithms. A Fintech provider, on the other hand, is defined as an individual or company that uses a technology platform, whether online or offline, to provide new financial services or to improve the delivery of existing financial services. Ideally, a provider would qualify to be termed a Fintech provider if it uses technology (whether online or offline) to provide, or to improve, the delivery of financial services such that the number of hurdles between requesting for a financial service and receiving the financial service is significantly reduced for users of financial services. However, in practice, the technology adopted by some self-identifying Fintech providers do not significantly reduce the hurdles that customers must go through between requesting for a financial service and receiving the financial service. Then cast doubts on whether these individuals or companies should be termed 'Fintech', and the debate about whether to de-classify such companies as 'Fintech' is still on-going in some countries. Fintech is an acronym for financial technology, which can be interpreted as a way of payment through an electronic or information technology. It is the convergence of financial service and information technology that provide innovative services offered to people. Two most known solution in worldwide may be Apple Pay and Google Wallet.

Fintech companies play an important role in the digital finance economy. Fintech providers are emerging in the financial services sector to either compete with banks or to complement the functions of banks to their customers. In the real world, some Fintech companies provide financial services at a higher cost while the cost of obtaining financial services from banks is relatively lower but the lengthy process of waiting to obtain a loan from regulated banks is making customers turn away from bank providers to non-bank providers.

For instance, a customer that walks into a bank on Monday requesting for $£ 70,000$ loan is not likely to obtain the full loan amount requested for on Monday, and this phenomenon is attributed to the fact that bank regulators and banks' internal risk management procedures require banks to spend a considerable amount of time to assess whether an individual qualify to receive a loan or not [15].

Despite the high cost of obtaining financial services from nonbank providers, individuals and companies with low and/or volatile income still prefer to use the services of non-bank providers, many of whom are not currently regulated in emerging countries and in most African countries. Finally, Fintech companies are diverse, and their diversity largely depends on available technology whether online or offline. Examples of Fintech businesses are those that engage in quick check-cashing services, payday lending, and related services.

Finally, the activities of Fintech providers can have implications for financial inclusion and stability.

Nevertheless, significant obstacles remain for the growth of Fintech in structural and institutional spheres and in the field of politics both in our country and in countries that are oversea. We call them new challenges that we face and that require an immediate solution. 
There are benefits of doing business with Fintech providers. There are reasons why individuals would rely on Fintech providers even though federally insured banks can provide the same financial services to customers at lower costs than Fintech providers. One, Fintech providers can provide quicker financial services with a seamless process, making it easier for low income individuals to manage their financial obligations on a day to day basis.

Two, Fintech providers do not handle deposits like banks which implies that Fintech providers will face fewer regulations (or will be unregulated in some countries) and the low regulatory burden they face makes it easier for Fintech providers to focus on improving their financial technology and intermediation function while reducing cost, where possible, to serve customers better.

Three, Fintech providers can partner with traditional lending institutions which can help them reduce operational costs and improve the quality of their intermediation activities.

Partnering with traditional lending institutions can help Fintech providers become sustainable over time, and the financial technology of Fintech providers can add value to the activities of the traditional lending institutions they partner with, particularly in 'process improvement' for their online lending business.

Four, some Fintech providers have superior ability to provide instant emergency funds or loans in small amounts to individuals with low and poor incomes compared to banks and other lending institutions. This is because conventional banks and other lending institutions are not obliged to provide emergency funds to anyone, and any request for emergency funding at a conventional bank or lending institution must go through the usual credit risk assessment process, which may be too lengthy for individuals that need instant emergency funds. This puts some Fintech providers in a better position to provide emergency funds in small amounts at higher interest rates to individuals with middle and low incomes.

Five, there is the potential for technology to provide convenience.

Fintech providers that operate via online platforms can electronically provide increased convenience to users by providing access to such services and making it available always from any location where the user or consumer can access the Internet. This enables Fintech providers to help customers to avoid having to travel to a banking hall to undertake financial transactions [16].

\section{Results and Discussion}

\subsection{Development indicators of foreign financial technologies}

The FinTech affects financial stability. It also entails credit, liquidity, concentration and operational risks, as well as macro-financial and other risks to financial stability, in particular those associated with pro-cyclical, shadow banking and the integrity of financial transactions. Although these risks are not new, they may increase due to the rapid growth of FinTech, new forms of interconnectedness.

The development of FinTech is gaining speed after a late start in some countries of the Middle East, North Africa, Afghanistan and Pakistan (BHAPA), and the first steps in its development are noted in the Caucasus and Central Asia (CCA) region. In both regions, FinTech can help address critical challenges in expanding access to financial services, inclusive growth and economic diversification through innovations that help reach a large portion of the population that does not have bank accounts with financial services, and also help to find alternative sources of financing for small and medium enterprises (SMEs). FinTech can also make a significant contribution to financial stability by using technology to ensure regulatory compliance and risk management, as well as boosting trade and remittance 
by creating efficient and cost-effective cross-border payment mechanisms, while using electronic payments can increase public administration efficiency [17].

The last few years have been marked by a rapid increase in global investment in FinTech and their further active growth is predicted. The amount of investment in FinTech increased more than 10 times from 2012 to 2015 (Figure 1 and Figure 2). Although consolidation in the US FinTech sector led to a reduction in global investment in 2016, growth continued in other regions, including the Middle East and North Africa (MENA), and there was a significant recovery in investment in the first half of 2017.

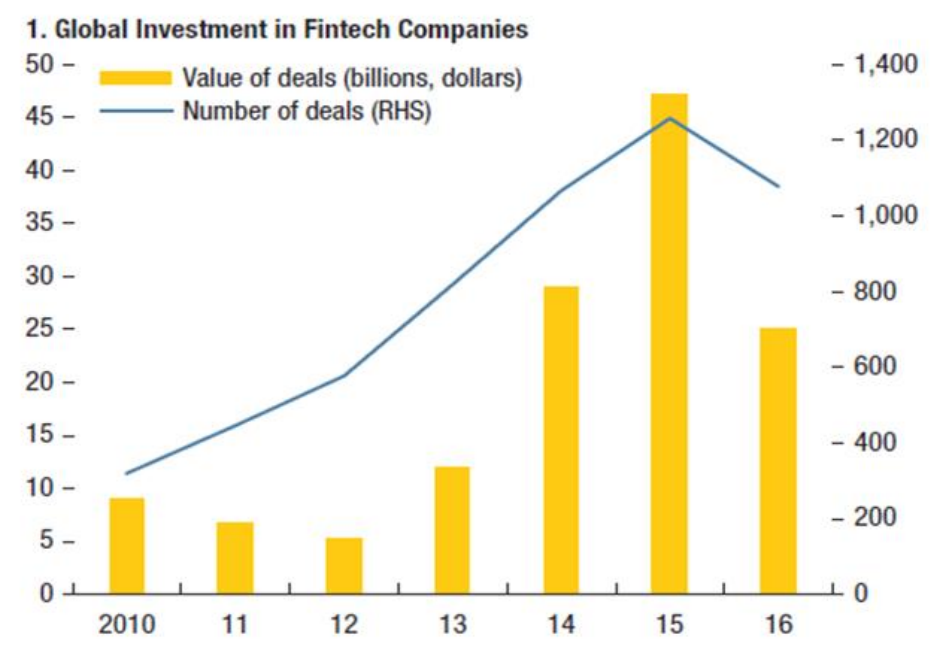

Fig. 1. Global Trends on Fintech: Global Investment in Fintech Companies, IMF.

In the CCA region, the FinTech ecosystem is still being formed, but there is an active trend towards the introduction of FinTech by existing banks and other companies. In this region, investments in digital financial services are still mainly carried out by banks, with Armenia and Kazakhstan apparently occupying leading positions in this area.

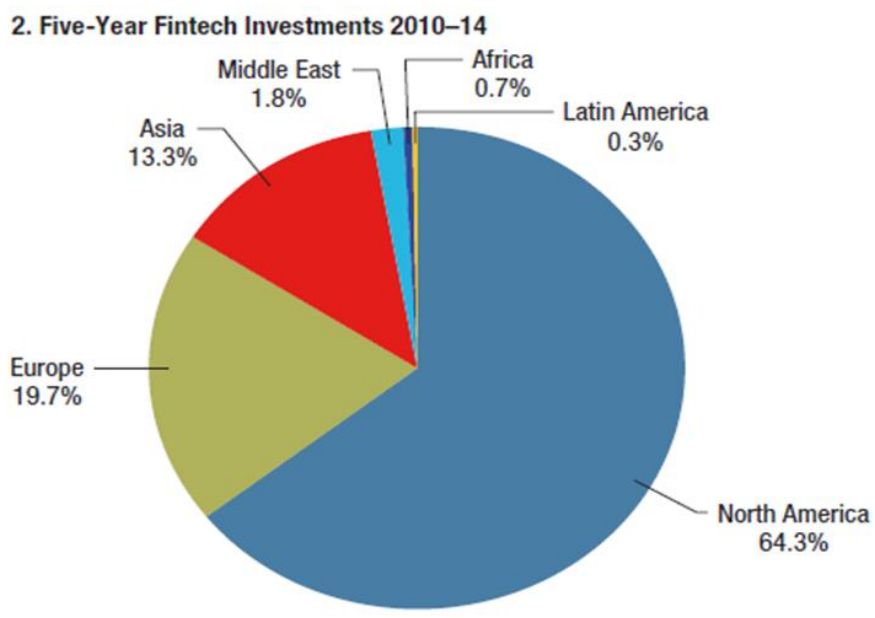

Fig. 2. Global Trends on Fintech: Five-Year Fintech Investments 2010-14 
The main part of investments in FinTech in the CCA region is in the payments and lending segments, which is in line with global trends. In addition, investments in financial technologies are still small, but also focused on solutions in the field of payments (mobile wallets, cryptocurrency).

The transition to digital technology can help improve the collection of government revenues and payments, and the increased use of electronic payments can counteract fraud and facilitate the effective transfer of monetary policy impact. In particular, Oman is already introducing a system of state electronic payments, and Kazakhstan plans to issue government bonds using TPP and mobile telephony.

Indicatively, the adoption rate for the six markets from our first survey - Australia, Canada, Hong Kong, Singapore, the UK and the US - has surged from $16 \%$ in 2015, to $31 \%$ in 2017 , to $60 \%$ in 2019 (Figure 3). Over the course of five years, these six markets have become excellent case studies in the maturation and globalization of the industry. In the past 18 months, EY research has shown that more than half of the top FinTech fundraises in these six markets intend to use some or all of funds raised for international expansion.

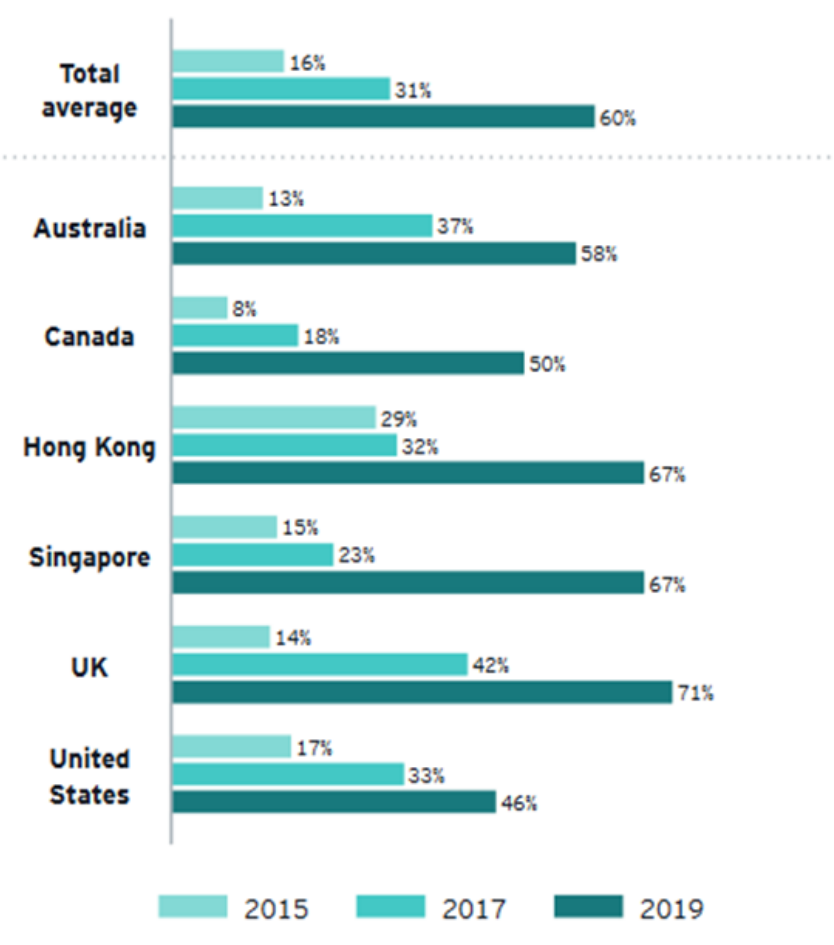

Note: the figure show adoption rates per market for the six markets for which a comparison is available

Fig.3. Comparison of Fintech adaptation in six markets from 2015 to 2019.

The adoption rate is growing faster than anticipated. The actual global adoption rate of $64 \%$ in 2019 exceeds by 12 points the 52\% future adoption rate predicted by our 2017 survey.

What's behind the strong growth in FinTech adoption? One reason: Incumbents have entered the fray in a big way. Markets with a sharp rise in adoption from 2017 to 2019, such as Ireland, the Netherlands and Singapore, reflect the availability of FinTech services offered by banks, insurers, stock brokers and other incumbent financial institutions [18]. 


\subsection{Challenges of foreign financial technologies}

Nevertheless, significant obstacles remain for the growth of FinTech in structural and institutional spheres and in the field of politics [17]:

1. There is still a lack of private investment capital and venture capital, which serve as the basis for financial growth in advanced economies. For example, the amount of investment in private equity and venture capital in MENA remains at around \$ 1 billion and even declined in the context of low oil prices.

2. Gaps in regulation create legal uncertainty that hinders the growth of this sector. Although the basics of regulating digital financial services are being developed, and most countries now have laws regulating the issuance of electronic money, in other regulatory areas related to financial technology, progress is not so significant. For example, only in a few countries (Egypt, Morocco, Tunisia) there are regulations on mobile money. In many countries, the fundamentals of protecting consumers of financial services and data secrecy laws have also not been established (World Bank, 2014). Prudential standards were not adjusted to the specifics of FinTech, and the high capital requirements of banks are a serious obstacle for FinTech startups.

3. General institutional support is still limited. Only very few countries have created incubators and accelerators (Egypt, Lebanon, United Arab Emirates) to promote the expansion of startups, or "regulatory sandboxes" (Abu Dhabi, Bahrain, Saudi Arabia), so that FinTech companies and traditional financial organizations can test innovative developments in real conditions.

4. In the field of demand, "lack of trust" and low financial literacy are serious obstacles for the activities of FinTech startups. The use of FinTech in making payments requires confidence to reduce uncertainty and curb the growth of transaction costs. The "lack of trust" is also cited as one of the main factors of more widespread cooperation between FINTECH start-ups and banks.

5. Cyber-attacks can lead to disruptions in work, financial loss, damage to reputation and systemic risk, and can create severe constraints if cybersecurity systems are not strengthened. Cyber risks are not unique to the FinTech field, but increasing interconnectivity based on digital solutions increases the number of entry points that hackers can take advantage of. In addition, although there were only a few cases of successful cyber-attacks on financial institutions in BVSAP and CCA, the number of attacks on banks in the region is reportedly increasing, and the nature of cybercrime is changing rapidly and becoming more sophisticated. Meanwhile, the overall readiness to counter cyber risks in many countries remains low.

Thera are Top barriers that have been indicated by Financial Sector Overview. Russia,CIS and the Caucasus report of the Astana International Financial Centre (AIFC) [19] :

1. Low appeal for foreign investors

2. Low purchasing power of the population

3. Deficiencies of government regulation of the industry

4. Geopolitical risks

5. Lack of flexibility in the tax system

6. Cyber threats

7. Currency risks

8. Weak protection of the personal data

\subsection{Indicators of financial technologies of Kazakhstan}

The state program "Digital Kazakhstan" [20] was adopted in our country, the goals of which are to accelerate the development of the economy of the Republic of Kazakhstan and 
improve the quality of life of the population through the use of digital technologies in the medium term, as well as creating conditions for transition Kazakhstan's economy to a fundamentally new development trajectory ensuring the creation of a digital economy of the future in the long term.

To achieve the above objectives, it is necessary to develop in the following two directions:

1. "Digitalization of the existing economy" - ensuring a pragmatic start consisting of specific projects in the real sector, launching projects on digitalization and technological reequipment of existing sectors of the economy, government structures and the development of digital infrastructure.

2. "Creating the digital industry of the future" - ensuring long-term sustainability, launching a digital transformation of the country by increasing the level of human capital development, building institutions for innovation development and, in general, the progressive development of the digital ecosystem (Figure 4).

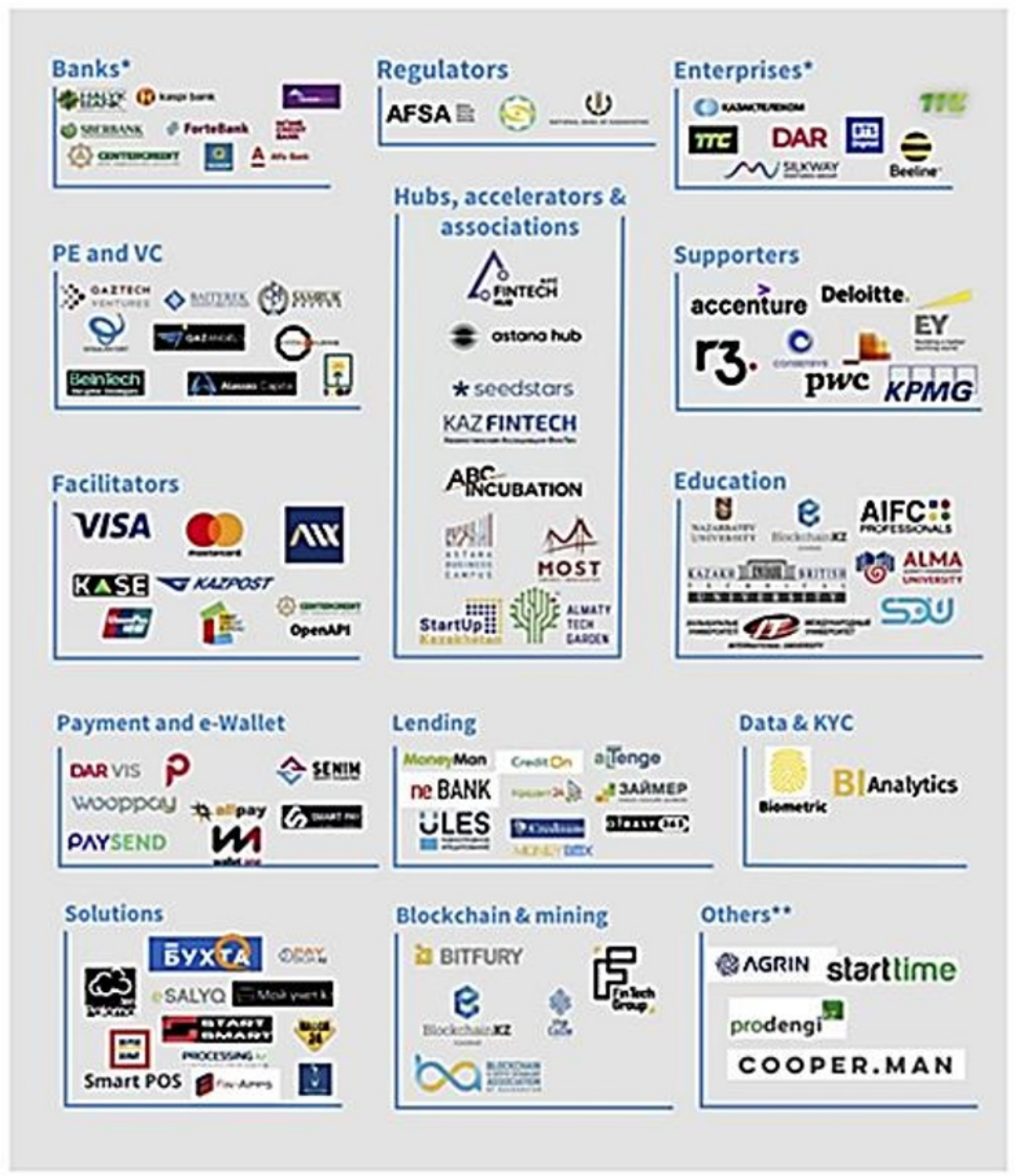

Fig.4. Fintech Ecosystem in Kazakhstan by AIFC. 
No branch of Kazakhstan can no longer ignore the process of "digitalization". The financial industry has traditionally been a leader in the implementation and application of innovative technologies and digital services for interacting with customers:

- almost all banks provide services through remote channels: $70 \%$ of banks provide services to individuals through the Internet and mobile banking, 55\% of banks provide services based on mobile applications;

- over 7 million people are already served through remote banking systems;

- the volume of payments via the Internet and mobile devices has increased by more than 2 times over the year;

- over $70 \%$ of legal entity payments are made via remote channels;

- the volume of payments to individuals using the Internet and mobile banking in 2016 compared to 2015 increased by 2.6 times;

- for investors, the procedure for providing electronic services by brokers was simplified, including trading on the basis of a client's digital signature and provision of electronic services through a personal account. This simplified access to the market for regional investors and allowed investors to trade in financial instruments on the Kazakhstan stock market from anywhere in the world.

Over the past few years, fintech has had a significant impact on the transformation of the global financing sector. The research identified the four most promising segments in the region: payments and lending, digital banking and marketplaces.

The development of the above segments in the region depends on the creation and effective operation of the Fintech ecosystem. This can be achieved by means of developing technologies and increasing demand for Fintech services and products through the adoption of a complex of measures aimed at providing capital for Fintech companies and improving the regulatory environment and talent pipeline [19].

\section{Conclusion}

All of the above data suggests the modernization of the ongoing processes in the financial sector of Kazakhstan, within the framework of which the effectiveness of the monetary policy in the country is much higher.

At the same time, new challenges are emerging that are facing new opportunities. New challenges to further digitalization of financial relations are the absence in the Republic of Kazakhstan:

- effective regulation;

- unified standards for the electronic interaction of the financial sector with state information systems and databases;

- universal mechanism for remote client identification;

- insufficient financial literacy of the population;

- fraud.

As Daniyar Akishev noted, today banks are gradually moving to customer service online in 24/7/365 format. to open bank accounts now, payment cards, deposits, receive loans, it is not necessary to come to the bank office. Services are provided online. For these purposes, a number of banks use biometric technologies - voice recognition, face scanning based on a photograph or video image.

As already mentioned, some banks use biometric technology. However, according to experts, it is necessary to create a common identification system. The new system should become a kind of "biometric passport" of the client, available to all banks, so that the client, once having got such a "document", can be serviced in other banks.

"We need some tools that would allow us to identify the client at the country level. The first step is to first understand whether this client is really the one for which he is trying to 
pass himself off. Because we all understand perfectly well: as soon as all the processes turn into a "digit", this will be a field for digital fraud. Therefore, the remote identification system is one of the problems," said Assem Nurgaliyeva [21].

The risks of cyber threats are increasing with the development of new technologies. In this regard, the National Bank should pay special attention to measures to protect information and financial infrastructure. Thus, the evolutionary nature of FinTech requires constant monitoring in order to identify and eliminate emerging risks to financial stability. As FinTech spreads, regulators and central banks should give priority to monitoring macro financial risks and preventing the use of new technologies for fraud, money laundering and terrorist financing; identifying and managing the operational risks associated with third-party service providers; and maintaining the sustainability of financial institutions and the reliable and efficient functioning of payment systems in the light of the growing role of non-financial companies. The oversight capacity needs to be strengthened so that it remains relevant and effective.

\section{References}

1. Asian Development Bank (ADB), Making Mobile Financial Services Work for Central and West Asian Countries (Manilla, 2014)

2. K. O. Amoako, E. O. Marfo, K. E. Gyau, \& F. O. Asamoah, Canadian Social Science, 9 (5), 188-191 (2013)

3. B. B. Howard, \& M. Upton, Introduction to business finance (McGraw-Hill, 1953)

4. F. E. Brigham, J. F. Houston, Fundamentals of Financial Management, 8, 688 (Cengage Learning, 2014)

5. G. Reinaldo, O. Dione, Revista Contabilidade \& Finanças, 24 (63), 181-194 (2013)

6. W. Lazonick, Business History Review, 84 (4), 675-702 (2010)

7. L. Stanciu, Buletin stiintific, 18 (1), 56-64 (2013)

8. S. Ziyadin, R. Doszhan, A. Borodin, A. Omarova, \& A. Ilyas, E3S Web of Conferences, 135, 04022 (2019) DOI: 10.1051/e3sconf/201913504022

9. S. Ziyadin, R. Doszhan, G. Saparova, A. Omarova, Proceedings of the 32nd International Business Information Management Association Conference, IBIMA 2018 - Vision 2020: Sustainable Economic Development and Application of Innovation Management from Regional expansion to Global Growth, 3379-3383 (2018)

10. S. Ziyadin, B. Ermekbaeva, G. Supugaliyeva, R. Doszhan, Proceedings of the 31st International Business Information Management Association Conference, IBIMA 2018: Innovation Management and Education Excellence through Vision 2020, 20092017 (2018)

11. S. Ziyadin, A. Omarova, R. Doszhan, G. Saparova, \& G. Zharaskyzy, Problems and perspectives in management, 16(4), 331-343 (2018). DOI: 10.21511/ppm.16(4).2018.27

12. K. Mukhtarova, S. Ziyadin, S. Kupeshova, \& R. Doszhan, Economic annals-XXI, 168, 38-43 (2017). DOI: 10.21003/ea.V168-08

13. J. A. Schumpeter, The theory of economic development: An inquiry into profits, capital, credit, interest, and the business cycle (1912/1934), 244 (Transaction Publishers, 1982)

14. World Bank, Global Survey on Consumer Protection and Financial Literacy. Oversight Frameworks and Practices in 114 Economies (Washington, DC, World Bank, 2014).

15. P. K. Ozili, Borsa Istanbul Review, 18 (4), 329-340 (2018)

16. P. K. Ozili, International journal of managerial finance, 13 (4), 419-439 (2017)

17. International Monetary Fund, Department of the Middle East and Central Asia: Fintech: unleashing the potential of the regions BVSAP and CCA (2017)

18. EY, Global FinTech Adoption Index (2019) 
19. Astana International Financial Centre (AIFC), Financial Sector Overview. Russia, CIS and the Caucasus report (2019)

20. Decree of the Government of the Republic of Kazakhstan dated December 12, 2017 No. 827.: Gosudarstvennaya Programma "Tsifrovoy Kazakhstan": [The state program "Digital Kazakhstan"] Foresight-Russia (2018)

21. Business Information Center Kapital https://kapital.kz/ 